\title{
PENGARUH PENGGUNAAN SISTEM SCADA PADA KEANDALAN JARINGAN DISTRIBUSI PT. PLN AREA MASOHI
}

\author{
D. B. Paillin \\ Program Studi Teknik Industri, Fakultas Teknik Universitas Pattimura, Ambon \\ Galang Pradipta \\ PLN Wilayah Maluku dan Maluku Utara, Ambon
}

\begin{abstract}
ABSTRAK
Penelitian ini bertujuan untuk mengetahui pengaruh sebelum dan sesudah penggunanan system SCADA terhadap keandalan jaringan distribusi PT. PLN Wilayah Maluku dan Maluku Utara Area Masohi. Hasil penelitian menunjukan adanya peningkatan indeks keandalan setelah terintegrasi dengan sistem Supervisory Control And Data Acquisition (SCADA) dengan parameter indeks System Average Interruption Duration Index (SAIDI) sebesar 15,04 Jam/pelanggan dan System Average Interruption Frequency Index (SAIFI) sebesar 14,92 kali/pelanggan serta penghematan sebesar Rp 35.369.361
\end{abstract}

Kata Kunci : Keandalan Jaringan, SCADA, SAIDI, SAIFI

\begin{abstract}
This study aims to determine the pre and post effect of SCADA system utilization on the distribution network reliability of PT. PLN Area Masohi. Results show the increasing reliability index after integration of Supervisory Control and Data Acquisition (SCADA) system which System Average Interruption Frequency Index (SAIFI) index parameter is 14,92 times/customers and saving of Rp 35.369.361.
\end{abstract}

Keywords: Network Reliability, SCADA Systems, SAIDI Systems, SAIFI Systems

\section{PENDAHULUAN}

Keandalan penyaluran energi listrik ke konsumen sangat dipengaruhi oleh sistem pendistribusiannya. Untuk itu diperlukan sistem distribusi energi listrik dengan keandalan yang tinggi. Keandalan pada sistem distribusi yang dimaksud adalah ukuran tingkat ketersediaan pasokan listrik dan seberapa sering sistem mengalami pemadaman serta berapa lama pemadaman terjadi (berapa cepat waktu yang dibutuhkan untuk memulihkan kondisi pemadaman yang terjadi). Dalam penyaluran tenaga listrik, tingkat keandalaan Jaringan Tegangan Menengah (JTM) sangat diperlukan karena ini merupakan faktor yang sangat berpengaruh terhadap kesinambungan penyaluran energi listrik sampai ke konsumen. Untuk mendapatkan keandalan yang tinggi, penerapan sistem SCADA (Supervisory Control and Data Aquisition) pada jaringan distribusi energi listrik sangatlah diperlukan, dimana kelebihan dari sistem SCADA yaitu dapat memantau, mengendalikan, mengkonfigurasi dan mencatat kerja sistem secara real time (setiap saat), serta mampu menangani gangguan yang bersifat permanen ataupun yang bersifat sementara/temporer dalam waktu yang singkat secara remote (jarak jauh) dari pusat kontrol.

Dengan Kondisi Sistem Area Masohi saat ini yang masih tinggi Nilai SAIDI (System Average Interruption Duration Index) nya yaitu sebesar 1.538 Menit/Pelanggan dengan Target yang ditetapkan Sebesar 614,07 Menit/Pelanggan dan SAIFI (System Average Interruption Frequency Index) nya yaitu sebesar 19,83 Kali/Pelanggan dengan Target yang ditetapkan Sebesar 14,58 Kali/Pelanggan, serta belum adanya Penerapan Sistem SCADA untuk Pemulihan jaringan Distribusi, Maka diharapakan dengan diterapkannya integrasi sistem SCADA pada Area Masohi dapat memberikan kualitas pelayanan yang lebih baik (efektif dan efesien) kepada konsumen listrik, dan dari pihak penyedia tenaga listrik sendiri (dalam hal ini PT.PLN persero) bisa meminimalisir terjadinya kerugian finansial akibat keandalan sistem yang rentan gangguan. Di samping itu, pemeliharaan jaringan secara rutin terjadwal dan evaluasi kerja sistem melalaui data-data harian yang ada, baik data gangguan maupun data pembacaan pengukuran dari peralatan sistem juga sangat diperlukan karena hal ini dapat membantu meningkatkan keandalan pada jaringan distribusi energi listrik. 
Tujuan dari penelitian ini adalah untuk mengetahui pengaruh penggunaan sistem SCADA sebelum adanya SCADA dan setelah adanya SCADA terhadap keandalan Jaringan Distribusi PT.PLN Wilayah Maluku dan Maluku Utara Area Masohi.

\section{LANDASAN TEORI}

Pengertian Keandalan

Keandalan adalah suatu penerapan perancangan pada komponen sehingga komponen dapat melaksanakan fungsinya dengan baik, tanpa kegagalan, sesuai rancangan atau proses yang dibuat. Keandalan merupakan probabilitas bahwa suatu sistem mempunyai performansi sesuai dengan fungsi yang diharapkan dalam selang waktu dan kondisi operasi tertentu. Secara umum keandalan merupakan ukuran kemampuan suatu komponen beroperasi secara terus menerus tanpa adanya kerusakan, tindakan perawatan pencegahan yang dilakukan dapat meningkatkan keandalan sistem.

\section{Keandalan Sistem Distribusi}

Keandalan Sistem Distribusi adalah ukuran tingkat ketersediaan pasokan listrik dan seberapa sering sistem mengalami pemadaman serta berapa lama pemadaman terjadi (berapa cepat waktu yang dibutuhkan untuk memulihkan kondisi pemadaman yang terjadi).(Julianto, dkk, 2014)

\section{Cara Menghitung Keandalan Sistem Distribusi}

Untuk mengukur suatu keandalan suatu sistem maka diperlukan patokan/standar yang berguna untuk menilai keadaan sistem dalam kondisi baik ataupun kurang baik. Maka berdasarkan Kontrak Manajemen PLN Tahun 2019 menetapkan bahwa sistem dalam kondisi baik jika telah memenuhi standart seperti dibawah :

$>$ SAIFI : $14,58 \mathrm{kali} /$ pelanggan

$>$ SAIDI : 0,614 jam/pelanggan

Dan pada Parameter pengukuran Laju kegagalan dan juga Switching Time berdasarkan SPLN pada tahun 1985 tentang Keandalan system Distribusi $20 \mathrm{kV}$ dan $6 \mathrm{kV}$ yaitu :

Standart Nilai Laju Kegagalan Dan Repair Time

\begin{tabular}{cccc}
\hline No. & Komponen & Laju Kegagalan & Repair Time (jam) \\
\hline 1 & Saluran Udara & $0,2 / \mathrm{km} /$ tahun & 4 \\
2 & Pemutus Tenaga & $0,004 /$ univ/tahun & 10 \\
3 & Sakelar Pemisah & $0,003 /$ unit/tahun & 10 \\
4 & Sakelar Beban & $\mathbf{0 , 0 0 3 / \text { unit tahun }}$ & 10 \\
5 & Trafo Distrihusi & $\mathbf{0 , 0 0 5 / \text { unit/tahun }}$ & 10 \\
\hline
\end{tabular}

\section{Menghitung Indesks Keandalan}

Sedangkan indeks-indeks keandalan yang digunakan untuk menghitung performa keandalan sistem secara keseluruhan yaitu :

A. SAIFI (System Average Interruption Frequency Index),

Menginformasikan tentang frekuensi pemadaman rata-rata untuk tiap konsumen dalam kurun waktu setahun pada suatu area yang dievaluasi, cara menghitungnya yaitu total frekuensi pemadaman dari konsumen dalam setahun dibagi dengan jumlah total konsumen yang dilayani. Secara matematis dituliskan sebagai:

di mana:

$$
S A I F I=\Sigma(\lambda i \times N i) \Sigma N(\text { kali/tahun } * \text { pelanggan })
$$

$\lambda=$ indeks kegagalan rata-rata per tahun (kali/pertahun)

$\mathrm{N}=$ jumlah konsumen padam

B. SAIDI (System Average Interruption Duration Index),

Menginformasikan tentang durasi pemadaman rata-rata untuk tiap konsumen dalam kurun waktu setahun pada suatu area yang dievaluasi, cara menghitungnya yaitu total durasi pemadaman dari konsumen dalam setahun dibagi dengan jumlah total konsumen yang dilayani. Secara matematis dituliskan sebagai: 
di mana:

$\mathrm{U}=$ Durasi kegagalan rata-rata per tahun (hour/year)

$\mathrm{N}=$ jumlah konsumen padam

\section{Jaringan Distribusi}

Pada dasarnya energi listrik dibangkitkan oleh beberapa pusat-pusat pembangkit (PLTA, PLTD, PLTU, PLTGU, dan pembangkit lainnya) dengan tegangan keluaran yang bervariasi 6-20 KV. Umumnya pusat pembangkit tenaga listrik berada jauh dari pusat pengguna listrik (pusat beban) oleh karena itu diperlukan sebuah sistem transmisi tenaga listrik dengan tegangan tinggi, mulai dari $70 \mathrm{KV}-500 \mathrm{KV}$ tergantung besar daya dan jarak antara pusat pembangkit dengan gardu induknya (Marsudi, D. 2006).

Tujuan menaikan tegangan generator dari pusat pembangkit melalui trafo step up menjadi tegangan tinggi dan disalurkan pada sistem transmisi adalah untuk efisiensi penyaluran tenaga listrik, efisiensi yang dimaksud antara lain pengunaan penampang penghantar, karena arus yang mengalir akan menjadi lebih kecil apabila tegangan transmisi dinaikan.

Setelah sampai pada gardu induk (GI) tegangan transmisi kemudian diturukan kembali melalui trafo step down menjadi tegangan $20 \mathrm{KV}$. Sebuah gardu induk (GI) pada dasarnya adalah pusat beban suatu pembangkit tenaga listrik, dimana energi listrik yang ada pada gardu induk (GI) akan disuplai ke pengguna beban melalui jaringan distribusi tegangan menengah $20 \mathrm{KV}$ untuk industri-industri besar dan diturunkan kembali menjadi tegangan rendah 220/380 V untuk pengguna beban sedang dan kecil. Ilustrasi penyaluran tenaga listrik dari pusat pembangkit hingga sampai ke jaringan tegangan menengah di tunjukan pada gambar berikut ini:

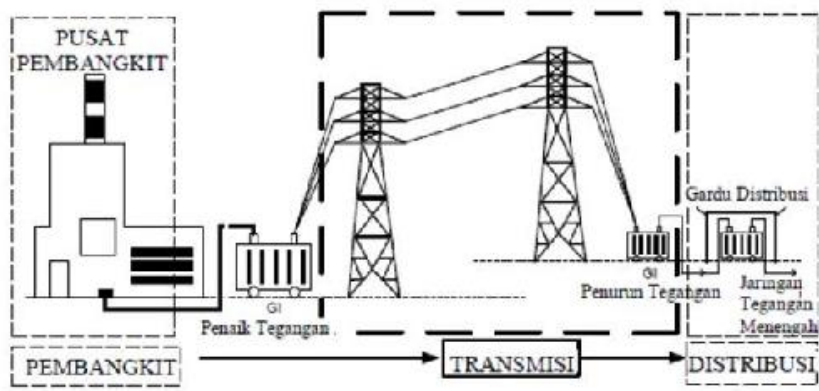

Penyaluran tenaga listrik

\section{Gangguan Pada Jaringan Distribusi}

Gangguan pada jaringan distribusi energi listrik dapat bersifat temporer dan permanen. Pada gangguan temporer sifatnya hanya sementara hal ini biasanya diakibatkan oleh flash over antara penghantar dan tiang, sambaran petir ataupun flash over dengan pohon-pohon yang berada di sekitar jaringan distribusi. Saat gangguan temporer terjadi dispatcher atau operator distribusi tidak perlu melakukan tindakan recovery (pemulihan) yang signifikan, karena gangguan tersebut akan hilang dengan sendirinya dan sistem distribusi energi listrik akan kembali berjalan normal. Sedangkan pada saat gangguan permanen terjadi, dispatcher atau operator distribusi harus melakukan tindakan recovery (pemulihan) jaringan untuk menjaga stabilitas, kontinyunitas dan kualitas tenaga listrik yang disalurkan kepada konsumen. Gangguan permanen dapat disebabkan oleh banyak faktor, adapun diantaranya adalah menurunnya ketahanan isolasi minyak trafo akibat overload yang mengakibatkan kerusakan permanen pada trafo tersebut, gangguan permanen juga dapat disebabkan oleh hubung singkat antar fasa yang menyebabkan terbukanya pemutus daya (PMT), dan gangguan permanen yang disebabkan oleh faktor lainnya. Gangguan Permanen juga dapat menyebabkan kondisi Black Out Sistem yaitu kondisi dimana jaringan listrik mengalami padam total dari Pembangkitan sampai Distribusi.

\section{Pengertian Umum SCADA}

SCADA (Supervisory Control And Data Acquisition) adalah sistem yang dapat memonitor dan mengontrol suatu peralatan proses atau sistem dari jarak jauh secara real time. SCADA berfungsi mulai dari pengambilan data pada Gardu Induk, Gardu Distribusi dan jaringan listrik tegangan menengah, pengolahan informasi yang diterima sampai reaksi yang ditimbulkan dari hasil pengolahan informasi. 
Secara umum fungsi dari sistem SCADA adalah penyampaian data, proses kegiatan dan monitoring, fungsi control, dan perhitungan dan pelaporan.

Tujuan digunakannya sistem SCADA adalah :

$>$ Mempercepat proses pemulihan suplai tenaga listrik bagi konsumen yang mengalami gangguan

$>$ Memperkecil $\mathrm{kWh}$ padam akibat gangguan atau pemadaman

$>$ Memantau performa jaringan untuk menyusun perbaikan atau pengembangan sistem jaringan $20 \mathrm{kV}$

$>$ Mengusahakan optimasi pembebanan jaringan $20 \mathrm{kV}$

\section{Fungsi Utama SCADA}

Untuk dapat menjalankan tugasnya, dispatcher dibantu oleh sistem SCADA yang terintegrasi yang berada di dalam suatu ruangan khusus yang disebut Control Center. Ruangan tersebut adalah ruangan dimana ditempatkannya perangkat-perangkat komputer yang disebut Master Station. Sedangkan fungsi utama dari sistem SCADA adalah akurasi data dan konversi data.

\section{Pemrosesan Data}

Setiap data yang dikirim oleh RTU akan diolah di master station, sehingga data tersebut bisa langsung ditampilkan ke layar monitor dan dispatcher bisa membaca data-data tersebut.

\section{Supervisory Data}

Dispatcher dapat mengawasi dan mengontrol peralatan sistem tenaga listrik. Supervisory control selau menggunakan operasi dua tahap untuk meyakinkan keamanan operasi, yaitu pilihan dan tahap eksekusi.

\section{Pemrosesan Event dan Alarm}

Event adalah setiap kejadian dari kerja suatu peralatan listrik yang dicatat oleh SCADA. Misalnya, kondisi normally close (N/C) dan kondisi normally open (N/O). Sedangkan alarm adalah indikasi yang menunjukkan adanya perubahan status di SCADA. Semua status dan alarm pada telesinyal harus diproses untuk mendeteksi setiap perubahan status lebih lanjut untuk event yang terjadi secara spontan atau setelah permintaan remote control yang dikirim dari control center.

\section{Tagging (Penandaan)}

Tagging adalah indikator pemberi tanda, seperti tanda masuk atau keluar. Tagging sangat bermanfaat untuk dispatcher di control center. Tagging digunakan untuk menghindari beroperasinya peralatan yang diberi tanda khusus, juga untuk memberi peringatan pada kondisi yang diberi tanda khusus.

\section{Post Mortem Review}

Melakukan rekonstruksi bagian dari sistem yang dipantau setiap saat yang akan digunakan untuk menganalisa setelah kejadian. Untuk melakukan hal ini, control center mencatat terus menerus dan otomatis pada bagian yang telah didefinisikan dari data yang diperoleh. Post mortem review mencakup dua fungsi, yaitu pencatatan dan pemeriksaan.

\section{Sistem SCADA}

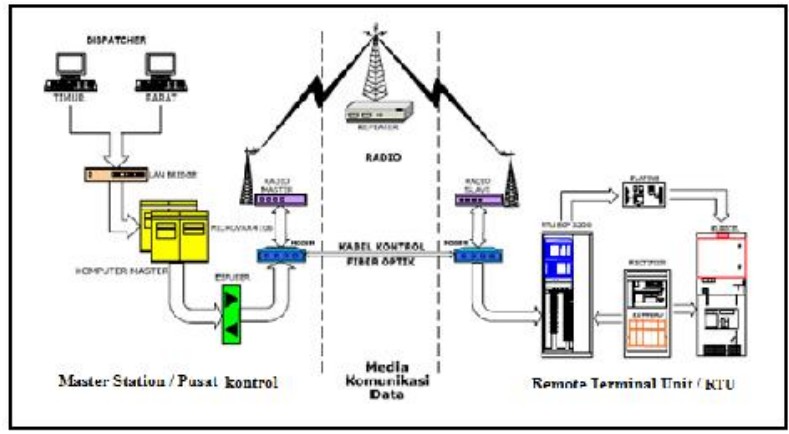

Arsitektur SCADA

Sumber: Materi Diklat Scada PLN 
Gambar diatas menjelaskan bahwa SCADA merupakan suatu sistem pengawasan, pengendalian dan pengolahan data sistem tenaga listrik secara real time. Komponen SCADA meliputi Master Station, media telekomunikasi, dan Remote Station/Remote Terminal Unit (RTU). SCADA mendapatkan data secara real time baik dari Remote Terminal Unit (RTU) atau sumber komunikasi lainnya yang ada di lapangan, sehingga operator (dispatcher) memungkinkan untuk melakukan pengawasan (supervisory) operasi jaringan tenaga listrik dan pengendalian peralatan pemutus beban jarak jauh (remote controle operation).

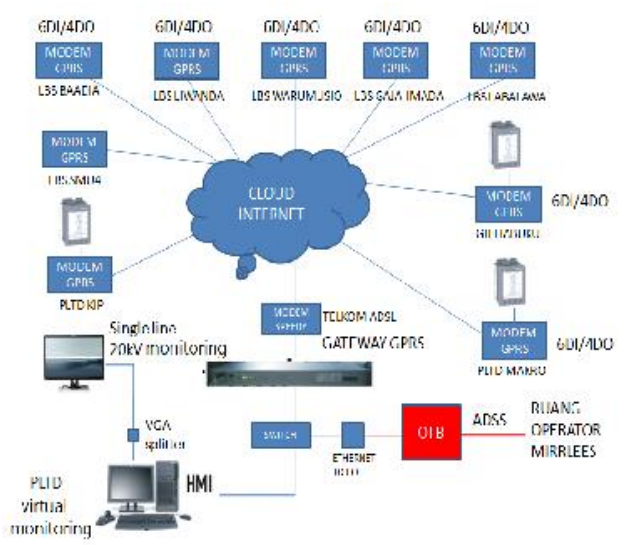

SCADA yang terintegrasi dengan sistem operasi tenaga listrik menggunakan media GPRS

Pada gambar diatas, merupakan suatu sistem operasi tenaga listrik yang terintegrasi dengan sistem SCADA menggunakan media GPRS, Dimana komputer yang ada di pusat kontrol (control centre) akan melakukan kontak dialog/berkomunikasi secara virtual dengan setiap Remote Terminal Unit (RTU) yang ada pada pertalatan listrik (LBS, Feeder, Trafo) secara bergilir dengan periodik waktu tertentu, pada proses ini dikenal dengan istilah scaning time. Waktu yang diperlukan komputer pusat kontrol untuk mendapatkan data-data dari Remote Terminal Unit (RTU) saat proses scaning adalah 10 detik, artinya data-data yang ada pada komputer pusat kontrol (pembacaan pengukuran Arus, Tegangan, Daya aktif dan reaktif serta status peralatan) akan diperbaharui (di- refresh) setiap 10 detik dan setiap pembaharuan data akan disimpan secara otomatis pada Hard Drive komputer pusat kontrol.

Media telekomunikasi yang digunakan sebagai perantara pengiriman data dari Remote Terminal Unit (RTU) ke Master Station ada beberapa macam, diantaranya adalah Power Line Carrier (PLC), Fiber Optic Network, Radio Link/GPRS dan Media komunikasi lainnya.

\section{Pengaruh Penggunaan SCADA Pada Sistem Distribusi}

Penerapan sistem SCADA pada jaringan distribusi energi listrik dapat mengefesiensikan waktu pengendalian dan pemulihan jaringan listrik, dapat memperkecil area pemadaman dan meningkatkan pelayanan penyaluran listrik kepada konsumen. Dengan sistem SCADA dapat dilakukan manuver beban apabila terjadi gangguan. Beban yang dibelakang titik gangguan dari arah gardu induk yang semula mensuplai kearah gangguan dapat dipindahkan ke gardu induk lainnya, sehingga suplai energi listrik ke beban yang bebas gangguan tetap dapat di distribusikan. (Andre, 2016)

\section{METODE PENELITIAN}

Variabel dan Definisi Operasional

Variabel keputusan dapat dinotasikan dengan lambang X. Yang termasuk dalam indikator variabel keputusan dalam penilitian adalah sebagai berikut :

a. Jam pada pelanggan $\left(\mathrm{X}_{1}\right)$

b. Rupiah padam $\left(\mathrm{X}_{2}\right)$

Variabel keputusan merupakan suatu indikator untuk mencapai variabel tujuan. Yang mana variabel tujuan adalah Efisiensi Penggunaan SCADA.

\section{Metode Analisa Data}

Analisis data yang digunakan dalam penelitian ini adalah metode SCADA terhadap keandalan jaringan distribusi energi listrik dari berbagai sumber, baik dari materi pembelajaran tentang SCADA maupun artikel-artikel yang ada di internet. 
Berikut ini merupakan flowchart dari penelitian ini.

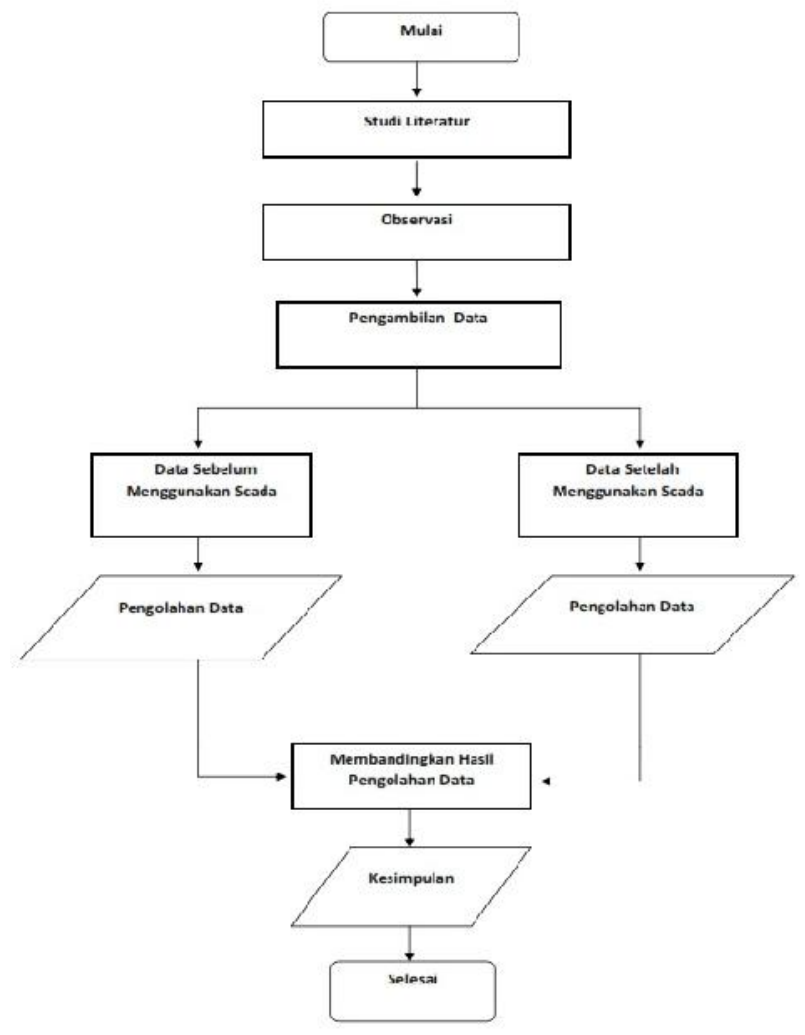

Flowchart Penelitian

\section{HASIL DAN PEMBAHASAN}

\section{Cara Kerja Sistem SCADA}

SCADA merupakan teknologi yang menggabungkan fungsi pengawasan, pengendalian dan pemerolehan/pengambilan data jarak jauh (remote area) yang terpusat pada suatu tempat yang disebut Control Center. Pada Control Center terdapat sebuah atau beberapa Human Machine Interface (HMI) atau Man Machine Interface (MMI) berupa monitor maupun layar besar yang terdapat digram-diagram jaringan yang memperlihatkan kondisi proses di lapangan ataupun keadaan peralatan nun jauh di sana yang terintegrasisistem SCADA. Seperti pengertian di atas, seorang dispatcher secara jarak jauh mampu melakukan perintah (Remote Control/Manuver) terhadap peralatan yang diawasi maupun mengambil data yang diperlukan dari peralatan tersebut. Seperti contohnya dalam jaringan listrik tegangan tinggi, dispatcher jika diperlukan dapat melakukan manuver menutup/membuka PMT (CB) pada suatu switchyard atau juga mengambil data besaran Voltage, Ampere maupun beban listrik di suatu jaringan secara real time.

Apakah komponen-komponen dalam SCADA yang dapat memungkinkan hal-hal tersebutdi atas dapat dilakukan? Yang pertama adalah RTU atau Remote Terminal Unit. RTU merupakan sebuah alat yang diletakkan di site (remote area) yang ingin diintegrasikandengan sistem SCADA, misalnya Switchyard, Gardu Listrik ataupun Relay Room. RTU pada Area Masohi ini adalah menggunkan LBS Remote. Di dalam RTU terdapat seperangkat CPU yang telah terprogram sehingga mampu meneruskanperintah dari Control Center ke peralatan maupun mengirimkan sinyal-sinyal alarm danbesaran-besaran (V, I, freq) dari peralatan ke Control Center. Didalam CPU tersebut terdapat perangkat seperti modem, memory (ROM) dan processor. Yang kedua adalah media telekomunikasi, sebagai media untuk menyampaikan pesan/sinyal antara RTU dengan Control Center dan sebaliknya. Media komunikasi bisa berupa media kabel, power line carrier, sinyal gsm, serat optik maupun frekuensi radio . Yang ketiga adalah protokol, komunikasi antara Control Center dengan RTU di remote area memanfaatkan sebuah protokol, contohnya HNZ, Indactic 33, maupun IEC 60870. Dan yang terakhir 
adalah Control Center seperti yang telah dijelaskan sebelumnya diatas. Di control center dispatcher mampu melakukan semua fungsi SCADA memanfaatkan perangkat-perangkat IT seperti mimic display (HMI), komputer dan server. Jadi dari penjelasan singkat di atas, terjadi proses sistematis berupa pengawasan,pengendalian dan pengambilan data dari Control Center terhadap peralatan di lapangan yang terpasang Remote Terminal Unit melalui media telekomunikasi yang semuanya dijalankan secara automatis oleh program yang diatur dan diawasi oleh dispatcher.

\section{Implementasi Scada pada PLN Area Masohi}

A. Sebelum Menggunakan SCADA

Sebelum penggunaan SCADA diterapkan, kegiatan pemulihan jaringan distribusi di Area Masohi masih menggunakan tenaga manual yaitu dengan menggunakan pihak ketiga disini yantek atau pelayanan teknik untuk mengatasi gangguan. Tugas dari yantek ini adalah untuk membantu menjalankan prosedur pemulihan jaringan yang terjadi akibat adanya gangguan. Kegiatan yantek sebelum adanya SCADA ini adalah melakukan Penormalan Gangguan dengan mengunjungi lokasi titik penormalan tersebut dengan mengendarai angkutan. Hal ini membuat kinerja PLN tentang SAIDI dan SAIFI meningkat serta kehilangan pendapatan karena banyak waktu terbuang untuk melakukan penormalan gangguan.

1. Analisa SAIDI dan SAIFI sebelum adanya SCADA

Nilai Saidi dan Saifi tahun 2016 sebelum adanya SCADA

\begin{tabular}{|c|c|c|c|c|c|c|c|c|}
\hline \multirow{2}{*}{ Bulan } & \multirow{2}{*}{ Area } & \multirow{2}{*}{ Jml PIgn } & \multirow{2}{*}{ Jml PIgn Padam } & \multirow{2}{*}{ Jam x PIgn Padam } & \multirow{2}{*}{ Menit x Plgn Padam } & \multicolumn{2}{|c|}{ SAIDI } & \multirow{2}{*}{ SAIFI } \\
\hline & & & & & & \begin{tabular}{|l|} 
Jam / PIgn \\
\end{tabular} & Menit / Plgn & \\
\hline Jan & Masohi & 38.566 & 17.076 & $24.040,03$ & $1.442 .401,80$ & 0,62 & 37,40 & 0,44 \\
\hline Feb & Masohi & 38.734 & 33.938 & 39.131 & $2.347 .833,00$ & 1,01 & 60,61 & 0,88 \\
\hline Mar & Masohi & 38.878 & 43.906 & $47.727,75$ & $2.863 .665,00$ & 1,23 & 73,66 & 1,13 \\
\hline Apr & Masohi & 39.047 & 83.476 & $67.657,10$ & $4.059 .426,00$ & 1,73 & 103,96 & 2,14 \\
\hline May & Masohi & 39.157 & 100.025 & $78.557,65$ & $4.713 .459,00$ & 2,01 & 120,37 & 2,55 \\
\hline Jun & Masohi & 39.321 & 121.425 & $97.537,05$ & $5.852 .223,00$ & 2,48 & 148,83 & 3,09 \\
\hline Jul & Masohi & 39.486 & 229.757 & $159.380,36$ & $9.562 .821,60$ & 4,04 & 242,18 & 5,82 \\
\hline Aug & Masohi & 39.736 & 281.100 & $187.787,42$ & $11.267 .245,20$ & 4,73 & 283,55 & 7,07 \\
\hline Sep & Masohi & 39.933 & 365.818 & $589.673,65$ & $35.380 .419,00$ & 14,77 & 885,99 & 9,16 \\
\hline Oct & Masohi & 40.200 & 458.331 & $740.236,51$ & $44.414 .190,60$ & 18,41 & $1.104,83$ & 11,40 \\
\hline Nov & Masohi & 40.392 & 669.245 & $865.067,79$ & $51.904 .067,40$ & 21,42 & $1.285,01$ & 16,57 \\
\hline Dec & Masohi & 41.069 & 814.338 & $1.052 .775,10$ & $63.166 .506,00$ & 25,63 & $1.538,06$ & 19,83 \\
\hline
\end{tabular}

Pada tabel diatas, dapat dijelaskan bahwa nilai SAIDI dan SAIFI tiap bulan bertambah dengan nilai SAIDI Komulatif sebesar 1.538,06 menit/pelanggan dan SAIFI Komulatif sebesar 19,83 kali pada bulan desember, nilai tersebut sangat tinggi dibandingkan dengan Target kinerja yang ditetapkan oleh Manajemen PLN yaitu SAIDI sebesar 615 menit/pelanggan dan SAIFI 14,58.

2. Analisa Waktu penormalan

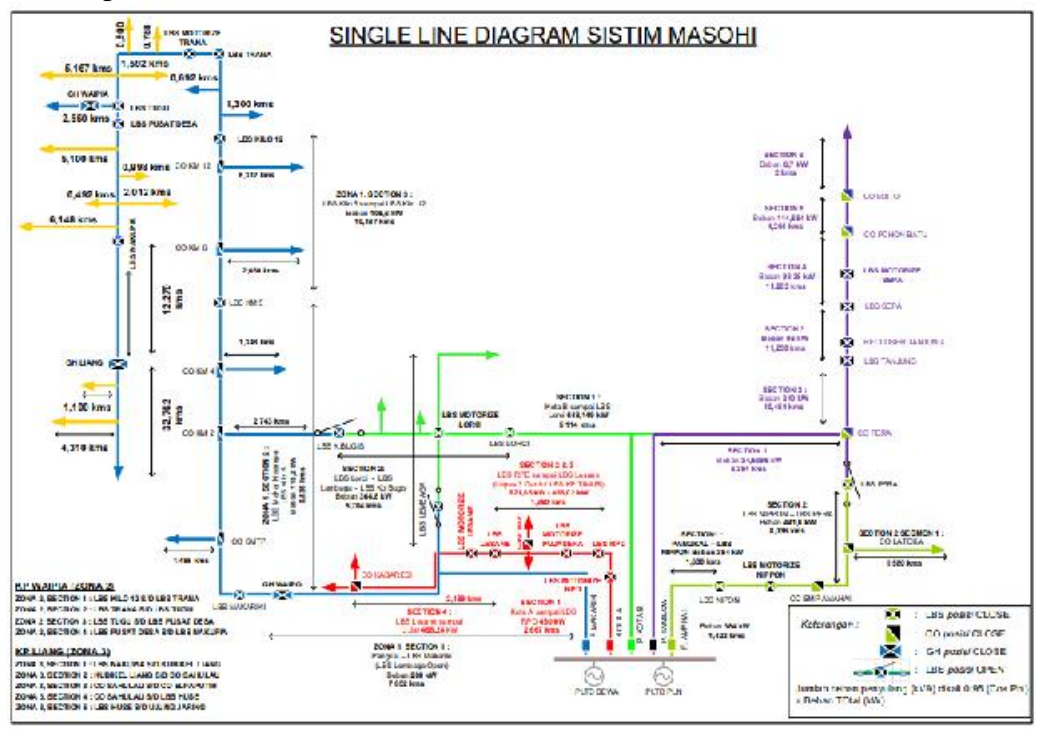

Single Line Diagram Sistim Masohi 
Analisa Rupiah padam sebelum adanya SCADA

\begin{tabular}{|c|c|c|c|c|c|c|c|c|}
\hline PRIORITAS & NAMA PENYULANG & SECTION & PANUANG PENYULANG (KMS) & LAMA PENORMALAN (JAM) & BEBAN PERSECTION ( $\mathrm{kW}$ ) & KWH PADAM & RUP & AH PADAM \\
\hline \multirow{6}{*}{1} & \multirow{4}{*}{ KOTAA } & 1 & 2,667 & 0,17 & 460 & $7 \epsilon, \epsilon 7$ & Ro & 112.491 \\
\hline & & 2 & 1,2 & 0,33 & 921,85 & 307,28 & Ru & 450.871 \\
\hline & & 3 & 0,66 & 0,50 & 456,02 & 228,01 & Ru & 334.555 \\
\hline & & 4 & 2,189 & 0,75 & $4 \Sigma 8,24$ & 373,68 & $R_{0}$ & $5<8.293$ \\
\hline & \multirow{2}{*}{ КОТАВ } & 1 & 5,114 & 0,83 & $648,14 D$ & 540,12 & $R_{0}$ & 792.513 \\
\hline & & 2 & $5, \pi$ & 0,92 & 361,8 & 334,10 & Ro & 190.658 \\
\hline \multirow{2}{*}{7} & \multirow{2}{*}{ AMAHA } & 1 & 1,63 & 1,08 & 384 & 416,00 & $R_{0}$ & 510.388 \\
\hline & & 2 & 8,036 & 1,17 & 441,6 & 515,20 & $R_{0}$ & 755.943 \\
\hline \multirow{7}{*}{3} & \multirow{5}{*}{ IVAKAKIKI } & 1 & 7.852 & 1,25 & 283 & 360,00 & Ro & 528.221 \\
\hline & & 2 & 6.525 & 1,42 & 115.2 & 163,20 & Ro & 239.460 \\
\hline & & 3 & $10,48 /$ & 1,58 & 105,6 & $16 \%, 20$ & Ko & $\angle<b .32 y$ \\
\hline & & 4 & 15,854 & 1,75 & 180,785 & 316,37 & Ro & 464.209 \\
\hline & & 5 & 32,762 & 2,00 & 115,045 & 230,09 & Ro & 337.606 \\
\hline & \multirow{2}{*}{ TAMILOUW } & 1 & 5,384 & 2,08 & 34,53396 & 71,55 & Ru & 105.565 \\
\hline & & 2 & 32,989 & 2,33 & $4 \beth 4,38$ & 1013,55 & $R_{0}$ & 1.4E7.167 \\
\hline \multicolumn{7}{|c|}{ TOTAL RUPIAHPADAM } & RD & 7.503 .269 \\
\hline
\end{tabular}

Pada tabel diatas, dijelaskan bahwa kondisi penormalan ini adalah pada saat Black Out sistim, dengan urutan Prioritas Penormalan, di dapatkan total rupiah padam sebesar Rp 7.503.269 apabila diketahui Rp/kWH adalah Rp 1467.28.

\section{B. Sesudah Menggunakan SCADA}

Sejak tahun 2017 dilakukan upgrade dalam hal sistem supervisi yang menjadikan SCADA menjadi suatu keharusan untuk kehandalan dan efisiensi operasional PLN khususnya APD sebagai pihak yang mengatur distribusi pasokan listrik. Setelah menggunakan SCADA, kebutuhan untuk melakukan pengawasan kelangsungan penyaluran tenaga listrik dengan melakukan pengumpulan informasi keadaan peralatan di lapangan dan mengambil tindakan atas dasar informasi tersebut secara remote/jarak jauh, real time dan terpusat sehingga didapat efisiensi dan efektifitas menyeluruh dalam operasional di LBS maupun pada Master Station.

1. Analisa SAIDI SAIFI setelah adanya SCADA

Nilai SAIDI dan SAIFI setelah adanya SCADA

\begin{tabular}{|c|c|c|c|c|c|c|c|c|}
\hline \multirow{2}{*}{ Bulan } & \multirow{2}{*}{ Area } & \multirow{2}{*}{ JmI PIgn } & \multirow{2}{*}{ Jml PIgn Padam } & \multirow{2}{*}{ Jam x Plgn Padam } & \multirow{2}{*}{ Menit x PIgn Padam } & \multicolumn{2}{|c|}{ SAIDI } & \multirow{2}{*}{ SAIFI } \\
\hline & & & & & & Jam / Plgn & Menit / PIgn & \\
\hline Jan & Masohi & 38.566 & 15.328 & $16.087,00$ & $965.220,00$ & 0,42 & 25,03 & 0,40 \\
\hline Feb & Masohi & 38.734 & 27.895 & 26.411 & $1.584 .660,00$ & 0,68 & 40,91 & 0,72 \\
\hline Mar & Masohi & 38.878 & 32.221 & $32.287,00$ & $1.937 .220,00$ & 0,83 & 49,83 & 0,83 \\
\hline Apr & Masohi & 39.047 & 49.097 & $47.726,00$ & $2.863 .560,00$ & 1,22 & 73,34 & 1,26 \\
\hline May & Masohi & 39.157 & 59.751 & $55.411,90$ & $3.324 .714,00$ & 1,42 & 84,91 & 1,53 \\
\hline Jun & Masohi & 39.321 & 72.189 & $68.287,70$ & $4.097 .262,00$ & 1,74 & 104,20 & 1,84 \\
\hline Jul & Masohi & 39.486 & 133.065 & $110.856,48$ & $6.651 .388,80$ & 2,81 & 168,45 & 3,37 \\
\hline Aug & Masohi & 39.736 & 171.265 & $126.733,08$ & $7.603 .984,80$ & 3,19 & 191,36 & 4,31 \\
\hline Sep & Masohi & 39.933 & 223.973 & $355.495,61$ & $21.329 .736,60$ & 8,90 & 534,14 & 5,61 \\
\hline Oct & Masohi & 40.200 & 302.417 & $441.390,61$ & $26.483 .436,60$ & 10,98 & 658,79 & 7,52 \\
\hline Nov & Masohi & 40.392 & 483.287 & $520.031,14$ & $31.201 .868,40$ & 12,87 & 772,48 & 11,96 \\
\hline Dec & Masohi & 41.069 & 612.749 & $618.304,92$ & $37.098 .295,20$ & 15,06 & 903,32 & 14,92 \\
\hline
\end{tabular}

Pada tabel diatas, dapat dijelaskan bahwa nilai SAIDI dan SAIFI tiap bulan bertambah dengan nilai SAIDI Komulatif sebesar 903,32 menit/pelanggan dan SAIFI Komulatif sebesar 14,92 kali pada bulan desember, nilai tersebut sudah menurun dibandingkan dengan sebeluma adanya SCADA walaupun Nilai tersebut belum memenuhi Target kinerja yang ditetapkan oleh Manajemen PLN yaitu SAIDI sebesar 615 menit/pelanggan dan SAIFI 14,58 karna masih banyak Gangguan Jaringan yang ada. 
2. Analisa Waktu Penormalan

Analisa Rupiah padam setelah adanya SCADA.

\begin{tabular}{|c|c|c|c|c|c|c|c|}
\hline PRIONITAS & NAMA PENYULANG & SLCTION & PANJANG PENYULANG (IOMS) & LAMA PENORMALAN (JAM) & DIBAN P LRSECTION (kW) & KWII PADAM & RUPIAII PADAM \\
\hline \multirow{6}{*}{1} & \multirow{4}{*}{ KOTA } & 1 & 2,667 & 0,03 & 460 & 15,33 & 22.498 \\
\hline & & 2 & 1,2 & 0.07 & 921,85 & 61,16 & 90.171 \\
\hline & & 3 & $0,0 \mathrm{C}$ & 0.10 & $45 G, 02$ & 45,60 & GC.911 \\
\hline & & 4 & 2,189 & 0.13 & 498,24 & 66.43 & 97.474 \\
\hline & \multirow{2}{*}{ KOTA E } & 1 & 5,111 & 0.17 & 618,119 & 108,02 & 158.503 \\
\hline & & 2 & 5,704 & 0.20 & 364,8 & 72,96 & 107.053 \\
\hline \multirow{2}{*}{2} & \multirow{2}{*}{ AIMAHAI } & 1 & 1,63 & 0.23 & 384 & 89,60 & 131.468 \\
\hline & & 2 & 8,036 & 0.27 & 111,6 & 117,76 & 172.787 \\
\hline \multirow{7}{*}{3} & \multirow{5}{*}{ MAK/RIKI } & 1 & 7,852 & 0,30 & 288 & 66,40 & $126.7 / 3$ \\
\hline & & $y$ & $h, h / h$ & $11+2$ & 11ר, & $+4 \times 41$ & it. 344 \\
\hline & & 3 & 10,487 & 0.37 & 105,6 & 38,72 & 56.813 \\
\hline & & 4 & 15,854 & 0.40 & 180.725 & 72,31 & 106.105 \\
\hline & & 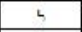 & 3), hl & 1143 & 114,1144 & 44,84 & $1+14 x$ \\
\hline & \multirow{2}{*}{ TAMILOUW } & 1 & 5,384 & 0.47 & 34,53396 & 16,12 & 23.646 \\
\hline & & 2 & 32,969 & 0.50 & 434,38 & 217,19 & 316.679 \\
\hline \multicolumn{7}{|c|}{ TOTAL RUPIAH PADAM } & Rp $\quad 1.608 .376$ \\
\hline
\end{tabular}

Pada tabel diatas, dijelaskan bahwa kondisi penormalan ini adalah pada saat Black Out sistim, dengan urutan Prioritas Penormalan, di dapatkan total rupiah padam sebesar Rp 1.608.376 rupiah diketahui Rp/kWH adalah Rp 1467.28.

Dengan adanya SCADA, PLN mendapatkan SAVING sebesar Rp 7.503.269 - Rp 1.608.376 = Rp 5.894 .893

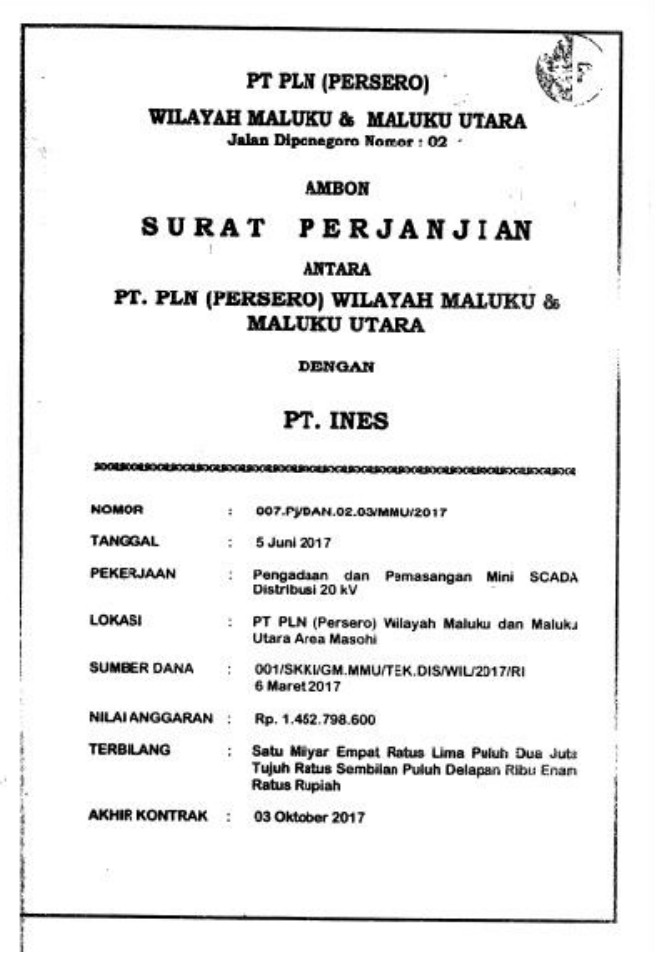

Kontrak Pengadaan dan Pemasangan Mini SCADA Distribusi 20 kV tahun 2017

Jika pada proses yang lama saat tidak menggunakan SCADA proses supervisi dilakukan secara manual, pada saat menggunakan SCADA proses tersebut diambil alih oleh komputer secara otomatis. Update informasi seperti telemetering, telestatus, dan telekontrol dilakukan setiap waktu tertentu dan hasilnya langsung terkirim secara otomatis hanya saat adanya perubahan nilai sehingga jaringan pada Master Station tidak dihujani trafik data secara berlebihan. Melalui proses ini, operator pada Master Station tidak perlu lagi mendata satu persatu setiap Section dalam wilayahnya karena hal tersebut sudah dilakukan melalui SCADA, terlebih lagi adanya HMI membuat operator lebih user friendly dalam melakukan pengawasan dan kemudahan memahami setiap masalah dan perubahan yang ada pada setiap Section. 
3. Analisa Kembali Modal

Dengan menggunakan SAVING yang di dapatkan setelah penggunaan SCADA maka dapat dihitung kembali modal pemasangan SCADA apabila dalam 1 tahun terjadi beberapa kali penormalan dengan data sebagai berikut :

Data Black Out Sistem Area Masohi

\begin{tabular}{|l|c|}
\hline \multicolumn{2}{|c|}{ Blackout Sistem Tahun 2016 } \\
\hline Bulan & Jumlah x BO \\
\hline Oktober & 1 \\
\hline November & \\
\hline Desember & $\mathbf{1}$ \\
\hline \multicolumn{2}{|c|}{ TOTAL }
\end{tabular}

\begin{tabular}{|l|c|}
\hline \multicolumn{2}{|c|}{ Blackout Sistem Tahun $\mathbf{2 0 1 7}$} \\
\hline \multicolumn{1}{|c|}{ Bulan } & Jumlah x BO \\
\hline Januari & 1 \\
\hline Februari & \\
\hline Maret & 1 \\
\hline April & 1 \\
\hline Mei & \\
\hline Juni & \\
\hline Juli & 1 \\
\hline Agustus & \\
\hline September & \\
\hline Oktober & \\
\hline November & \\
\hline Desember & $\mathbf{5}$ \\
\hline \multicolumn{2}{|c|}{ TOTAL } \\
\hline \multicolumn{2}{|c|}{} \\
\hline
\end{tabular}

\begin{tabular}{|c|c|}
\hline \multicolumn{2}{|c|}{ Blackout Sistem Tahun 2018} \\
\hline Bulan & Jumlah x BO \\
\hline \multicolumn{2}{|l|}{ Januari } \\
\hline \multicolumn{2}{|l|}{ Februari } \\
\hline Maret & 1 \\
\hline \multicolumn{2}{|l|}{ April } \\
\hline Mei & 1 \\
\hline \multicolumn{2}{|l|}{ Juni } \\
\hline Juli & 1 \\
\hline \multicolumn{2}{|l|}{ Agustus } \\
\hline September & 1 \\
\hline \multicolumn{2}{|l|}{ Oktober } \\
\hline \multicolumn{2}{|l|}{ November } \\
\hline \multicolumn{2}{|l|}{ Desember } \\
\hline TOTAL & 4 \\
\hline
\end{tabular}
berikut :

Rupiah Padam sebelum pemasangan SCADA pada Oktober 2016 - Oktober 2017 adalah sebagai

Jumlah Blackout (Penormalan) = 6 Kali (Oktober 2016 - Oktober 2017)

Rupiah padam sebelum pemasangan SCADA $=$ Rp 7.503.269 × 6

$$
=\operatorname{Rp} 45.019 .616
$$

Rupiah padam setelah pemasangan SCADA $=\mathrm{Rp} 1.608 .376 \times 6$

$$
=\operatorname{Rp} 9.650 .255
$$


Saving setelah pemasangan SCADA = Rp 45.019.616 - Rp 9.650.255

$=\operatorname{Rp} 35.369 .361$

Maka dapat kembali modal dapat diketahui dengan perhitungan sebagai berikut :

Kembali Modal = Investasi Pemasangan SCADA

$$
\begin{aligned}
& \text { SAVING } \\
& =\frac{\operatorname{Rp~1.452.798.600}}{\operatorname{Rp~35.369.361}} \\
& =41 \text { bulan }
\end{aligned}
$$

\section{KESIMPULAN}

Dari hasil penelitian, maka kesimpulan penelitian ini yaitu :

1. Jaringan Distribusi Energi Listrik pada PT. PLN (Persero) Area Masohi secara umum mengalami peningkatan indeks keandalan setelah terintegrasi dengan sistem SCADA dengan parameter indeks SAIDI sebesar 15,04 Jam/pelanggan dan SAIFI sebesar 14,92 kali/pelanggan.

2. Dengan adanya SCADA PT.PLN Area Masohi dapat melakukan SAVING rupiah padam sebesar Rp 35.369.361.

3. Dengan adanya SCADA PT.PLN Area Masohi mendapatkan kemudahan dalam proses penormalan sistem dengan cepat.

\section{DAFTAR PUSTAKA}

Andre, M. H. (2016). Analisis Keandalan Penggunaan Scada Pada Jaringan Distribusi 20 Kv Di PT. PLN (Persero) Feeder 15 Bangau Sakti Menggunakan Metode Reliability Network Equivalent Approach (RNEA), Tugas Akhir, Universitas Islam Negeri Sultan Syarif Kasim Riau.

Fardiana, D., (2003)., Sistem SCADA Pada Operasi Jaringan Spindle PT.PLN (persero) Distribusi Jakarta Raya dan Tanggerang, Universitas Gunadarma, Jakarta.

Julianto, K., Nugraha, D. W., \& Dodu, A. E. (2014). Evaluasi Penggunaan Scada Pada Keandalan Sistem Distribusi PT. PLN (Persero) Area Palu. Jurnal Mektrik, Vol. 1 No. 1., pp.1-10.

Soleh, Muhammad. (2014)., Desain Sistem SCADA Untuk Peningkatan Pelayanan Dan Efisiensi Operasional Sistem Tenaga Listrik di APJ Cirebon. Incom Tech, Jurnal Telekomunikasi Vol. 5.

SPLN No.59. 1985. Keandalan Pada Sistem Distribusi $20 \mathrm{kV}$ dan $6 \mathrm{kV}$, Perusahaan Umum Listrik Negara, Jakarta.

SPLN S6.001. 2008. Perencanaan dan Pembangunan Sistem SCADA, Perusahaan Umum Listrik Negara, Jakarta.

Wicaksono, H. P.( 2012)., Analisa Keandalan Sistem Distribusi PT.PLN (Persero) Wilayah Kudus Pada Feeder KDS 2, KDS 4, KDS 8, PTI 3 dan PTI 5. Menggunakan metode Section Technique dan Running Keandalan Software ETAP, Teknik Elektro Institut Teknologi Sepuluh Nopember, Surabaya. 
